Original Research Paper

\title{
Phenotypic Diversity of South African Indigenous Goat Population in Selected Rural Areas
}

\author{
${ }^{1,2}$ Tlou Caswell Chokoe, ${ }^{1}$ Tlou Cornelia Matelele, ${ }^{5}$ Ayanda Maqhashu, ${ }^{4}$ Fhulufhelo Vincent Ramukhithi, \\ ${ }^{1}$ Tumudi Desmond Mphahlele, ${ }^{3}$ Takalani Judas Mpofu, ${ }^{3}$ Khathutshelo Agree Nephawe and ${ }^{3}$ Bohani Mtileni \\ ${ }^{1}$ Department of Agriculture Land Reform and Rural Development: Farm Animal Genetic Resources, Private Bag X973, \\ Arcadia, 0001, Pretoria, RSA \\ ${ }^{2}$ School of Agriculture and Environmental Sciences, University of Limpopo: Turfloop Campus, Private BagX1106, Sovenga, \\ 0727, Polokwane, RSA \\ ${ }^{3}$ Department of Animal Science, Faculty of Sciences, Tshwane University of Technology, Private Bag X680, Pretoria, 0001, RSA \\ ${ }^{4}$ Agricultural Research Council, Private Bag X2, Irene, 0062, Pretoria, RSA \\ ${ }^{5}$ Department of Animal and Wildife Sciences, University of Pretoria, Pretoria, 0002, RSA
}

\author{
Article history \\ Received: 22-01-2020 \\ Revised: 28-02-2020 \\ Accepted: 24-03-2020 \\ Corresponding Author: \\ Tlou Caswell Chokoe \\ Department of Agriculture \\ Land Reform and Rural \\ Development: Farm Animal \\ Genetic Resources, Private Bag \\ X973, Arcadia, 0001, Pretoria, \\ RSA \\ Email: TlouC@daff.gov.za
}

\begin{abstract}
Phenotypic characterisation of indigenous goat populations is crucial in providing information on goat types and their attributes and may play an important role as guideline for conservation and sustainable us of these resources. The objective of this study was to characterise indigenous goat populations in rural areas of South Africa. Appearance of indigenous goat phenotypes and their typical features were observed from 297 individual goats. FREQ procedure of Statistical Analysis System was used to determine the descriptive statistics of the qualitative phenotypic variables. To detect the statistical differences for quantitative traits, the General Linear Model procedure of SAS was computed, whereas Fisher's Least Significant Difference test was used to separate the least square means $(P<0.05)$. Horns and toggles were the most dominant phenotypes found in the different regions, while the beard had low proportions across regions. Black coat colour was the dominant colour $(9.68-69.57 \%)$ of most of the populations in Mopani, Vhembe, Tshwane, Westrand, Bojanala, Motheo and Thabo Mofutsanyane regions. There was a significant $(P<0.05)$ difference in all phenotypic measurements, with higher $(P<0.05)$ values for body length $(48.23$ $\mathrm{cm})$, body weight $(26.86 \mathrm{~kg})$ and wither height $(64.61 \mathrm{~cm})$ observed in indigenous goats of Dr. Ruth Segomotsi Mompati (DRSM) region. Goats in Tshwane, Westrand and DRSM had significantly similar body length whilst also those in Motheo, Thabo and Vhembe had significantly similar body length. The indigenous goats of Thabo Mofutsanyana region had the highest $(P<0.05)$ value for rump length $(17.52 \mathrm{~cm})$, however have the shortest tail length $(7.17$ $\mathrm{cm}$ ) compared to those at other regions. Results from the study shows considerable phenotypic heterogeneity in qualitative traits of indigenous goat population and their distributions in different regions.
\end{abstract}

Keywords: Body Length, Characterization, Coat Colour, Phenotypes, Regions

\section{Introduction}

Indigenous goats in general are known to have the ability to survive and reproduce in harsh environmental conditions and on poor quality fibrous feeds. In developing countries, livestock production is mostly subsistence oriented and fulfills multiple functions that contribute more for food security (Roessler et al., 2008).
Characterisation of livestock breeds based on their morphological traits variations (Mavule et al., 2016; Delgado et al., 2001) is the first step towards the use of the available Animal Genetic Resources (Kunene et al., 2006; Lanari et al., 2003). Phenotypic quantitative characteristics are measures of animal body parts (Belay and Meseretu, 2017; FAO, 2012; Pieters et al., 2009) and are more directly associated to production characteristics when 
compared to phenotypic qualitative characteristics (Manzi et al., 2011; Jimcy et al., 2011).

Morphological diversity is a good reflector of ecological selection regimes and history of a breed (Mdladla et al., 2017; Kotze et al., 2014; González et al., 2011). In addition, phenotypes are an expression of genetic characteristics, modified by environmental conditions and variance in both genetics and environment may affect phenotypic variance (Kunene et al., 2014; Yakubu et al., 2010c; Riva et al., 2004).

Idowu and Adelabu (2018) stated that coat colour and certain characteristics provide goats with unique abilities. Coat colour is very amiable and irregular including black and brown, pied and mixed colour (Adedeji, 2012). It is influenced by a large number of genes that are involved in determining the presence, distribution and biochemical activities of the melanocytes (Okourwa, 2015; Fontanesi et al., 2011).

Although phenotypic characterisation is important in breed identification and classification, it is scanty in Gauteng, Free State, North West and Limpopo provinces. It is in the context of these assertions that this study depended on phenotypic measurements and geographic locations to unearth the characteristic of genetic diversity amongst indigenous goat populations. The objective of this study was to characterise indigenous goat populations in selected rural areas of South Africa based on a set of phenotypic traits.

\section{Materials and Methods}

\section{Study Site}

Data was collected in Mopani and Vhembe District Municipalities of Limpopo Province; Bojanala and Dr. Ruth Segomotsi Mompati (DRSM) Districts Municipalities of North West Province; Tshwane Metro Municipality and Westrand District Municipality of Gauteng Province and at Motheo and Thabo Mufutsanyana District Municipalities of Free State Province.

Limpopo province has a mild to moderate winters (9.8-20 $\left.{ }^{\circ} \mathrm{C}\right)$, hot summers $\left(22-30^{\circ} \mathrm{C}\right)$ and average annual rainfall of between 400 and $750 \mathrm{~mm}$ per annum. Gauteng province experiences mild to moderate winters $\left(8-20^{\circ} \mathrm{C}\right)$, hot summers $\left(21.2-27^{\circ} \mathrm{C}\right)$ and average annual rainfall of between 400 and $750 \mathrm{~mm}$ per annum. The average summer temperatures in North West province range from 18 to $36^{\circ} \mathrm{C}$, with extremes of up to $40^{\circ} \mathrm{C}$ whilst winter temperatures are moderate and range between 3 and $20^{\circ} \mathrm{C}$. Average rainfall of North West province varies between 300 and $600 \mathrm{~mm}$ per annum. In Free State province, mean annual temperatures vary between 7 and $10^{\circ} \mathrm{C}$ in winter and 18 and $30^{\circ} \mathrm{C}$ in summer and mean annual rainfall ranges between 300 and $750 \mathrm{~mm}$ (Schulze et al., 2010; Kruger and Sekele, 2013).

\section{Sampling of Households}

For each district, 3-8 villages were selected and households within a village were chosen using systematic random sampling procedure. A total of 297 does, were sampled from the 4 studied provinces of South Africa. The number of does sampled in each area were: Gauteng province: Tshwane Metro Municipality $=36$, Westrand District Municipality = 42, Free State province: Motheo District Municipality $=23$ and Thabo Mufutsanyana District Municipality = 36, North West province: Bojanala District Municipality $=34$, Dr. Ruth Segomotsi Mompati (DRSM) Districts Municipality = 44, Limpopo province: Mopani District Municipality $=46$, Vhembe District Municipality $=36$.

\section{Data Collection}

Age of each animal was determined by the dentition method. Only goats with two pairs of incisors and above (24 months old and above) were considered in order to minimise age effects. A scale was used to determine Body Weight (BW) of each animal sampled. Goats were weighed in the morning before feeding to minimize postprandial gut variation (Yakubu et al., 2010c). A textile measuring tape was used to obtain different body measurements from each sampled animal (with records taken to the nearest $\mathrm{cm}$ ) after restraining and holding the animal in an unforced position. The body parts were measured as described by Yakubu et al. (2010c). Phenotypic qualitative traits recorded were Head Length (HL), Head Width (HW), Ear Orientation (EO), Ear Length (EL), Heart Girth (HG), Body Length (BL), Wither Height (WH), Thorax Depth (TD), Rump Height (RH), Rump Width (RW), Rump Length (RL), Neck Circumference (NC) and Tail Length (TL). Records were also taken on qualitative traits such as: coat colour pattern, colour, horns length, ear orientation and presence or absent of beard and toggles.

\section{Statistical Analysis}

Frequencies and percentages of occurrence of qualitative traits were generated using the FREQ procedure of Statistical Analysis System (SAS Institute Inc., 2014). To detect the statistical differences for quantitative traits, the General Linear Model Procedure (PROC GLM) of the SAS was computed, whereas Fisher's Least Significant Difference (LSD) test was used to separate the least square means $(P<0.05)$. The following model was used:

$$
Y_{i k}=\mu+A_{i}+e_{i k}
$$

Where:

$Y_{i k}=$ The observations on linear body measurements 
$\mu=$ The underlying constant common to all observations

$A_{i}=$ Fixed effect of districts

$e_{i k}=$ Random residual/error

\section{Results}

\section{Indigenous Goat Phenotypic Diversity}

A considerable diversity of phenotypic characters such as horns, beard and toggles of indigenous goat population distributions in different regions of South Africa (\%) are presented in Table 1. The three common phenotypes of indigenous goat found in rural communities of South Africa include: Presence and absence of horns, beard and toggles. Horns and toggles were the most dominant phenotypes found in the different regions, while the beard phenotype observed in the current study had low proportions across regions. Beard and toggles phenotypes were observed to be high in Motheo region $(69.57 \%$ and $86.96 \%$ respectively). In Tshwane district there was a low observation of beard phenotype $(25.81 \%)$ and the toggle phenotype $(26.47 \%)$ were observed to be low in Vhembe region.

\section{Coat Colour Pattern}

The proportions of the different coat colour and patterns of indigenous goat populations in different regions of South Africa (\%) are presented in Table 2. Each population observed possessed multiple variants of coat colours, even though there were great variations among the different populations in the proportion of specific coat colours characterising them. Black coat colour was the dominant colour (9.68-69.57\%) of most of the populations in Mopani, Vhembe, Tshwane, Westrand, Bojanala, Motheo and Thabo Mofutsanyane regions. The second most popular coat colour that was dominant appeared to be a white colour (2.94-55.56\%) in most of the populations in Mopani, Vhembe, Tshwane, Westrand, Bojanala, Motheo and Thabo Mofutsanyane regions. DRSM region had a large proportions of light red $(59.09 \%)$ and fawn $(38.64 \%)$ coat colour in this study. The fawn coat colour was also observed in Vhembe region (17.65\%).

Farmers in Thabo Mofutsanyana region preferred a patchy coat colour pattern indigenous goat (69.444\%) than farmers in Tshwane region (19.35\%) who enjoy keeping indigenous goats with plain coat colour pattern $(58.06 \%)$. The higher proportion spotted coat colour pattern $(44.12 \%)$ was observed in Vhembe and Bojanala regions and appear to be distributed relatively fairly between the different regions than other observed coat colour patterns.

\section{Head Region Characteristics}

Table 3 shows the proportions (\%) of the different head region characters (horn shape and horn growth direction) of South African indigenous goats. The curved horn shape dominated (50.00-65.22\%) all regions except in Vhembe (32.35\%) and DRSM (20.45\%) regions. The straight and spiral shaped horn shape were observed to be dominant in Vhembe (41.18\%) and DRSM (45.45\%) regions. The backward horn growth directions constituted higher proportion in Tshwane $(80.65 \%)$, Thabo Mofutsanyana (66.67\%), Mopani (65.33\%), Motheo (65.22\%), Vhembe (44.12\%) and DRSM (43.18\%). Sideways and upright growth directions were observed to be dominant in Bojanala (64.71\%) and DRSM (34.09\%).

\section{Ear Region Characteristics}

The proportions of the different ear region characters (ear orientation and ear direction) of South African indigenous goats $(\%)$ are presented in Table 4 . The ear orientation and ear direction are the most prominent ear region characters on indigenous goats that were observed. Mopani, Motheo and Thabo Mofutsanyane regions have the higher proportion of erected eared goats, whilst Vhembe, Tshwane, Bojanala and DRSM regions have the higher proportion of semi-pendulous eared goats. However, indigenous goats in Westrand region have the higher proportions of pendulous ears. The higher proportion of stiff sideways ear direction was observed in indigenous goats of Westrand (87.88\%), Thabo Mofutsanyana (77.78\%), Bojanala (70.59\%), DRSM (63.64\%) and Vhembe $(61.76 \%)$ regions, whilst the higher proportion of those with soft hanging ear direction were observed in Mopani (89.13\%) and Tshwane (64.52\%) region.

\section{Body Region Characteristics}

The linear body measurements $(\mathrm{cm})$ of South African indigenous goats are presented in Table 5. There was a significant $(P<0.05)$ difference in all phenotypic measurements understudy, with higher $(P<0.05)$ values for body length $(48.23 \mathrm{~cm})$, body weight $(26.86 \mathrm{~cm})$ and wither height $(64.61 \mathrm{~cm})$ observed in indigenous goats of DRSM region. Indigenous goats in Tshwane, Westrand and DRSM had similar $(P>0.05)$ body length whilst also those in Motheo, Thabo and Vhembe had significantly similar $(P>0.05)$ body length. However, those in Mopani had significantly lower body length compared to those in other regions. Indigenous goats in Mopani Region have significantly higher $(P<0.05)$ values for thorax depth $(23.77 \mathrm{~cm})$, rump height $(57.78 \mathrm{~cm})$ and tail length $(7.93 \mathrm{~cm})$. The indigenous goats of Thabo Mofutsanyana region had the highest $(P<0.05)$ value for rump length $(17.52 \mathrm{~cm})$, however have the shortest tail length $(7.17$ $\mathrm{cm})$ compared to the indigenous goat of all regions. 
Table 1: Diversity of phenotypic characters of indigenous goat population distributions in different regions of South Africa (\%)

\begin{tabular}{lllll}
\hline Regions & $\mathrm{n}$ & Horns & Beard & Toggled \\
\hline Mopani & 46 & 100.00 & 34.78 & 73.91 \\
Vhembe & 34 & 100.00 & 41.18 & 26.47 \\
Tshwane & 31 & 100.00 & 25.81 & 70.97 \\
Westrand & 33 & 100.00 & 30.30 & 63.64 \\
Bojanala & 34 & 100.00 & 26.47 & 82.35 \\
DRSM & 44 & 100.00 & 65.91 & 38.64 \\
Motheo & 23 & 100.00 & 69.57 & 86.96 \\
Thabo Mofutsa & 36 & 100.00 & 47.22 & 61.11 \\
\hline
\end{tabular}

Table 2: The proportions (\%) of the different coat colour and coat colour patterns of indigenous goat populations in different regions of South Africa

\begin{tabular}{|c|c|c|c|c|c|c|c|c|c|}
\hline \multirow[b]{2}{*}{ Regions } & \multirow[b]{2}{*}{$\mathrm{n}$} & \multicolumn{5}{|c|}{ Coat colour } & \multicolumn{3}{|c|}{ Coat colour patterns } \\
\hline & & White & Black & Dark red & Light red & Fawn & Plain & Patchy/Pied & Spotted \\
\hline Mopani & 46 & 6.52 & 69.57 & 13.04 & 10,87 & 0.00 & 10.87 & 50.0 & 39.13 \\
\hline Vhembe & 34 & 2.94 & 38.24 & 23.53 & 17.64 & 17.65 & 14.71 & 41.17 & 44.12 \\
\hline Tshwane & 31 & 48.39 & 9.68 & 41.93 & 0.00 & 0.00 & 58.06 & 19.35 & 22.58 \\
\hline Westrand & 33 & 30.30 & 12.12 & 57.58 & 0.00 & 0.00 & 15.15 & 39.40 & 45.45 \\
\hline Bojanala & 34 & 52.94 & 20.59 & 26.47 & 0.00 & 0.00 & 11.76 & 44.12 & 44.12 \\
\hline DRSM & 44 & 0.00 & 0.00 & 2.27 & 59.09 & 38.64 & 13.64 & 43.18 & 43.18 \\
\hline Motheo & 23 & 47.83 & 52.17 & 0.00 & 0.00 & 0.00 & 8.70 & 65.21 & 26.09 \\
\hline Thabo Mofutsa & 36 & 55.56 & 27.78 & 16.66 & 0.00 & 0.00 & 16.67 & 69.44 & 13.89 \\
\hline
\end{tabular}

Table 3: Proportions of the different head region characters (horn shape and horn growth direction) of South African indigenous goats (\%)

\begin{tabular}{|c|c|c|c|c|c|c|c|}
\hline \multirow[b]{2}{*}{ Regions } & \multirow[b]{2}{*}{$\mathrm{n}$} & \multicolumn{3}{|c|}{ Horn shape } & \multicolumn{3}{|c|}{ Horn direction } \\
\hline & & Curved & Spiral & Straight & Backward & Sideways & Up-straight \\
\hline Mopani & 46 & 50.00 & 21.74 & 28.26 & 65.22 & 8.70 & 26.08 \\
\hline Vhembe & 34 & 32.35 & 26.47 & 41.18 & 44.12 & 41.17 & 14.71 \\
\hline Tshwane & 31 & 64.52 & 35.48 & 0.00 & 80.65 & 0.00 & 19.35 \\
\hline Westrand & 33 & 60.61 & 0.00 & 39.39 & 33.34 & 36.36 & 30.30 \\
\hline Bojanala & 34 & 52.94 & 8.82 & 38.24 & 11.76 & 64.71 & 23.53 \\
\hline DRSM & 44 & 20.46 & 45.45 & 34.09 & 43.18 & 22.73 & 34.09 \\
\hline Motheo & 23 & 65.22 & 0.0 & 34.78 & 65.22 & 34.78 & 0.00 \\
\hline Thabo Mofutsa & 36 & 58.33 & 30.56 & 11.11 & 66.67 & 13.89 & 19.44 \\
\hline
\end{tabular}

Table 4: Proportions of the different ear region characters (ear orientation and ear direction) of South African indigenous goats (\%)

\begin{tabular}{|c|c|c|c|c|c|c|}
\hline \multirow[b]{2}{*}{ Regions } & \multirow[b]{2}{*}{$\mathrm{n}$} & \multicolumn{3}{|c|}{ Ear orientation } & \multicolumn{2}{|l|}{ Ear direction } \\
\hline & & Erect & Pendulous & Semi-Pendulous & Soft hanging & Stiff sideways \\
\hline Mopani & 46 & 60.87 & 6.52 & 32.61 & 89.13 & 10.87 \\
\hline Vhembe & 34 & 5.88 & 2.94 & 91.18 & 38.24 & 61.76 \\
\hline Tshwane & 31 & 35.48 & 0.00 & 64.52 & 64.52 & 35.48 \\
\hline Westrand & 33 & 30.30 & 51.52 & 18.18 & 12.12 & 87.88 \\
\hline Bojanala & 34 & 29.41 & 29.41 & 41.18 & 29.41 & 70.59 \\
\hline DRSM & 44 & 11.36 & 43.19 & 45.45 & 36.36 & 63.64 \\
\hline Motheo & 23 & 56.52 & 4.35 & 39.13 & 47.83 & 52.17 \\
\hline Thabo Mofutsa & 36 & 72.22 & 11.11 & 16.67 & 22.22 & 77.78 \\
\hline
\end{tabular}

Table 5: Least square means \pm standard error for the quantitative body characters of indigenous goats in different regions of South Africa

\begin{tabular}{|c|c|c|c|c|c|c|c|c|}
\hline Traits $(\mathrm{cm})$ & Mopani & Vhembe & Tshwane & Westrand & Bojanala & DRSM & Motheo & Thabo Mofutsa \\
\hline$\overline{\mathrm{N}}$ & 46 & 34 & 31 & 33 & 34 & 44 & 23 & 36 \\
\hline Body length & $36.08^{c} \pm 1.07$ & $38.44^{\mathrm{b}} \pm 1.08$ & $46.97^{\mathrm{a}} \pm 1.16$ & $48.21^{\mathrm{a}} \pm 1.14$ & $39.06^{\mathrm{b}} \pm 1.10$ & $48.23^{\mathrm{a}} \pm 1.07$ & $39.07^{\mathrm{b}} \pm 1.08$ & $39.69^{\mathrm{b}} \pm 1.11$ \\
\hline Body weight & $22.59^{\mathrm{cd}} \pm 0.93$ & $21.92^{\mathrm{de}^{2}} \pm 0.94$ & $22.45^{\mathrm{cde}} \pm 1.01$ & $25.21^{\mathrm{b}} \pm 0.99$ & $20.96^{\mathrm{e}} \pm 0.95$ & $26.86^{\mathrm{a}} \pm 0.93$ & $25.26^{\mathrm{ab}} \pm 0.94$ & $23.64^{b c} \pm 0.96$ \\
\hline Heart girth & $73.23^{\mathrm{b}} \pm 1.04$ & $75.12^{\mathrm{a}} \pm 1.05$ & $74.07^{\mathrm{ab}} \pm 1.13$ & $74.07^{\mathrm{ab}} \pm 1.10$ & $73.55^{\mathrm{ab}} \pm 1.07$ & $74.82^{\mathrm{ab}} \pm 1.03$ & $70.04^{c} \pm 1.05$ & $74.29^{\mathrm{ab}} \pm 1.08$ \\
\hline Wither height & $61.76^{\mathrm{bc}} \pm 0.90$ & $61.50^{\mathrm{bc}} \pm 0.91$ & $63.05^{\mathrm{ab}} \pm 0.97$ & $61.81^{b c} \pm 0.95$ & $61.13^{c} \pm 0.92$ & $64.61^{\mathrm{a}} \pm 0.89$ & $62.39^{b c} \pm 0.91$ & $61.56^{\mathrm{bc}} \pm 0.93$ \\
\hline Thorax depth & $23.77^{\mathrm{a}} \pm 0.38$ & $23.65^{\mathrm{abc}} \pm 0.39$ & $23.64^{\mathrm{abc}} \pm 0.42$ & $23.34^{\mathrm{abc}} \pm 0.41$ & $23.07^{\mathrm{bcd}} \pm 0.40$ & $23.68^{\mathrm{ab}} \pm 0.38$ & $22.89^{\mathrm{cd}} \pm 0.39$ & $22.41^{\mathrm{d}} \pm 0.40$ \\
\hline Rump height & $57.78^{\mathrm{a}} \pm 1.27$ & $53.65^{\text {bcd }} \pm 0.27$ & $54.19^{b c} \pm 1.37$ & $51.88^{\mathrm{cd}^{\mathrm{d}}} \pm 1.34$ & $51.73^{\mathrm{d}} \pm 1.30$ & $55.05^{\mathrm{b}} \pm 1.26$ & $53.40 b^{c d} \pm 1.31$ & $53.27^{\mathrm{bcd}} \pm 1.31$ \\
\hline Rump length & $15.03^{\mathrm{d}} \pm 0.55$ & $16.07^{b c} \pm 0.55$ & $15.86 b^{c d} \pm 0.59$ & $15.56^{\mathrm{cd}} \pm 0.60$ & $16.42^{\mathrm{bc}} \pm 0.56$ & $16.68^{\mathrm{ab}} \pm 0.54$ & $15.37^{\mathrm{cd}} \pm 0.55$ & $17.52^{\mathrm{a}} \pm 0.57$ \\
\hline Rump width & $14.58^{b c} \pm 0.43$ & $15.62^{\mathrm{a}} \pm 0.44$ & $15.91^{\mathrm{a}} \pm 0.47$ & $14.40^{c} \pm 0.46$ & $14.29^{c} \pm 0.45$ & $15.46^{\mathrm{a}} \pm 0.43$ & $15.17^{\mathrm{abc}} \pm 0.44$ & $15.33^{\mathrm{ab}} \pm 0.45$ \\
\hline Tail length & $7.93^{\mathrm{a}} \pm 0.25$ & $7.84^{\mathrm{ab}} \pm 0.25$ & $7.90^{\mathrm{ab}} \pm 0.27$ & $7.54^{\mathrm{abc}} \pm 0.26$ & $7.49^{b c} \pm 0.25$ & $7.24^{c} \pm 0.25$ & $7.29^{c} \pm 0.25$ & $7.17^{\mathrm{c}} \pm 0.26$ \\
\hline
\end{tabular}

$\overline{a, b, c, d, e}$ Values with different superscripts within the same raw differs significantly $(P<0.05)$. Dr. Ruth Segomotsi Mompati $=$ DRSM; Thabo Mofutsanyana $=$ Thabo Mofutsa 


\section{Discussion}

The results show the presence of clear morphological variations between and within the indigenous goat populations in different areas of South Africa. Horns and toggles were the most dominant phenotypes found in the different regions, while the beard phenotype observed in the current study had low proportions across regions. The presence of horns in indigenous goats is an important adaptive feature for self-defensive mechanism to fight predators or where animals had to fight competitors for feed and water and even for does during mating (Katongole et al., 1996; Mdladla, 2016). The low occurrence of polledness in indigenous goat populations has been reported in Ghana (Hagan et al., 2012). The morphological differentiation were also observed in other species such as Zulu sheep populations in South Africa using multivariate analysis (Mavule et al., 2016).

Beard and toggles phenotypes were observed to be high in Motheo region. In Tshwane district there was a low observation of beard phenotype and the toggle phenotype are observed to be low in Vhembe region. Beard and toggles have been associated with many benefits in some studies (Adebayo and Chineke, 2011). Prominent among the benefits of toggles and beard are the thermoregulatory functions of beard and wattle and the association of these traits with reproduction such as higher prolificacy, higher milk yield, higher litter size, fertility index and conception rate (Osinowo et al., 1988; Yakubu et al., 2010c). Although further conclusions cannot be drawn on the current study regarding toggles/wattles based on the collected data. Yakubu et al. (2010a) reported an associated taboo towards toggled village goats which might be the case in the communities in the study.

Farmers relied on coat colour and patterns to identify their goats. Each population observed possessed multiple variants of body hair coat colours, even though there were great variations among the different populations in the proportion of specific body hair coat colours characterising them. Black body hair coat colour was the dominant colours of most of the populations in Mopani, Vhembe, Tshwane, Westrand, Bojanala, Motheo and Thabo Mofutsanyane regions. Morphological differences have important sociocultural and economic values to the rural communities and as a result, most farmers have specific consideration and choices for goat coat colors (Mahanjana and Cronje 2000; Gwaze et al., 2009). In Vhembe region, black goats are more preferred for rituals (Mashau, 2013) and are also believed to have good adaptation to cold weather as the black pigment helps warming them up faster than goats with other coat colours (Hassen et al., 2012). In Ghana, dark coat colors have been linked to environmental adaptation (Hagan et al., 2012).

The second most popular body hair coat colour that was dominant appeared to be a white colour in most of the populations in Mopani, Vhembe, Tshwane, Westrand, Bojanala, Motheo and Thabo Mofutsanyane regions. This is similar with the results of Hassen et al. (2012) on Ethiopian indigenous goats where he found that white colour has socio-cultural and economic values to African people. For example: black goats are less preferred in the Amhara region (Ethiopia) and Zululand region (South Africa) because they are believed to bring bad luck in the family (Bekalu, 2016; Pieters et al., 2009). Except for DRSM region which is comprised of a large proportions of light red and fawn body hair coat colour. The fawn body hair coat colour was also observed in Vhembe region amongst other regions. The body hair coat colour have a direct effect on goat marketing value (Mahanjana and Cronje, 2000; Kotze et al., 2014). These marketing abilities on indigenous goats brought by their unique coat colours and certain characteristics were stated by Idowu and Adelabu (2018) in their studies. However, in West Africa, based on the information gotten from the farmers, it was discovered that there is no preference coat colour amidst the farmers, but black coat colour are highly priced followed by brown herd in agreement with Adedeji et al. (2011).

The majority of smallholder farmers in all districts studied preferred patchy coat colour pattern. The plain coat colour patterns showed lower proportion in all the regions understudy except in Tshwane region, whilst the spotted coat colour pattern was distributed relatively fairly between the different districts. The variation in colours observed in the current study was not surprising, as it has been documented that South African indigenous goats have a variety of colours (Campbell, 2003; Morrison, 2007; Mdladla, 2016; Mdladla et al., 2017). This shows that South African indigenous goats in different areas of South Africa share some common characteristics.

Only nine basic phenotypic measurements (BL, BW, HG, WH, TD, RH, RL, RW and TL) consistently could be important in differentiating among indigenous goat populations, than acquiring a substantial number of measurements. Some of the measurements selected in the current study are similar to those obtained by earlier researchers (Traoré et al., 2008; Yakubu et al., 2010a; Yakubu et al., 2010b; Okpeku et al., 2011) in morphological differentiation of indigenous goats. The study revealed a significant $(P<0.05)$ difference in all phenotypic measurements understudy, with higher $(P<0.05)$ values for body length, body weight and wither height observed in indigenous goats of DRSM region. This was in agreement with the report of (Alade et al., 2008; Sowande et al., 2009; Semakula et al., 2010; Okbeku et al., 2011). The morphometrical studies involving Sahelian goat are scant:

Mohmmed and Amin (1997) reported mean HW in nonpregnant Sahelian does in Nigeria of $60 \mathrm{~cm}$; the mean HW of the Red Sokoto goat, which is considered a transition breed between Sahelians and Djallonkés present in 
Southern Niger, was $58.2 \mathrm{~cm}$ (Alade et al., 2008; Dossa et al., 2007); Bourzat et al., 1993). These values are, in general, consistent with that of HW reported here for the Sahelian goat (Sowande et al., 2009) which are similar to the results from this study.

Indigenous goats in Mopani region have significantly higher $(P<0.05)$ values for thorax depth, rump height and tail length. In other studies an average values for thorax depth was reported in the coastal goat population of Benin and were on average $24.69 \mathrm{~cm}$ (Dossa et al., 2007). The indigenous goats of Thabo Mofutsanyana region had the highest value for rump length, however have the shortest tail length compared to the indigenous goat of all regions. Morphometric measurements can be used to describe the animals' production status and breed characteristics (Cam et al., 2010). Previous studies have used multivariate analysis of morphological parameters to explain population structure, facilitate breed identification and estimate genetic variation within and between indigenous goat populations from different agro-ecological zones (Tsegaye et al., 2013).

\section{Conclusion}

Results from this study shows considerable phenotypic heterogeneity in qualitative traits of indigenous goat populations kept under extensive production system and their distributions in different regions of South Africa. From the three phenotypes of indigenous goats found in rural communities of South Africa include: Presence and absence of horns, beard and toggles while the beard phenotype observed in the current study had low proportions across regions. Black coat colour was the dominant colour of most of the populations. There was a significant difference in all phenotypic measurements understudy, with higher values for body length, body weight and wither height observed in indigenous goats. This phenotypic information could be useful to regulate the different phenotypes within a region or country and design some criteria for characterisation and description of the indigenous goat populations into breeds. Further complementary research into the effects of these traits and the underlying genes on economic factors should be undertaken for smallholder farmers-oriented breeding plans. The assessed phenotypic traits coupled with genetic information could be a powerful tool towards the promotion of conservation and utilization of indigenous goat genetic resources. For this reason, the level and distribution of genetic variation between South African indigenous goat populations using Single Nucleotide Polymorphisms require investigation.

\section{Acknowledgement}

The author wishes to acknowledge the Department of Agriculture Land Reform and Rural Development (DALRRD) for funding the project. Special thanks to
ARC-Germplasm Conservation and Reproductive Biotechnologies personnel for their assistance.

\section{Funding Information}

The author wishes to acknowledge funding of this manuscript and the project from the Department of Agriculture Land Reform and Rural Development (DALRRD): Directorate: Genetic Resources.

\section{Author's Contributions}

Tlou Caswell Chokoe, Fhulufhelo Vincent Ramukhithi and Bohani Mtileni: Were in charge of project design and writing the manuscript. TC Chokoe.

Tlou Cornelia Matelele, Tumudi Desmond Mphahlele, Ayanda Maqhashu and Takalani Judas Mpofu: Were in charge of project implementation. All co-authors participated in results, statistics and interpretation of the study.

\section{Ethics}

All animal procedures were performed in strict accordance with the guidelines of the Ethics Committee of the Department of Agriculture Land Reform and Rural Development, South Africa, which also approved this study.

\section{References}

Adebayo, J. and C. Chineke, 2011. Evaluation of West African dwarf goat for some qualitative traits in Southwestern Nigeria. African J. Agric. Res., 6: 6204-6207.

Adedeji, T.A., 2012. Effect of some qualitative traits and non-genetic factors on heat tolerance attributes of extensively reared West African Dwarf (WAD) goats. Int. J. Applied Agric. Apiculture Res., 8: 68-81.

Adedeji, T.A., M.O. Ozoje, S.O. Peters, L.O. Ojedapo and O.A. Sanusi, 2011. Effect of coat colour and wattle genes on morphometric characteristics and scrotal dimensions in traditionally reared West African Dwarf (WAD) bucks. Int. J. Agric. Environ. Biotechnol., 4: 157-162.

Alade, N.K., A.O. Raji and M.A. Atiku, 2008. Determination of appropriate model for the estimation of body weight in goats. Department of Animal Science, University of Maiduguri, Maiduguri, Borno State, Nigeria, ARPN J. Agric. Biol. Sci.

Bekalu, M., K. Kefelegn and M. Yoseph, 2016. Phenotypic characterization of indigenous goat types in West Gojjam Zone, Amhara National Regional State. Ethiopia. J. Biol. Agric. Healthcare, 6: 54-64. 
Belay, Z. and M. Meseretu, 2017. On farm phenotypic characterization of indigenous goat populations in Gamo Gofa zone South Western Ethiopia. J. Adv. Studies Agric., Biol. Environ. Sci., 4: 23-32.

Bourzat, D., P.S. Zafindrajaona, J.J. Lauvergne and V. Zeuh, 1993. Morpho-biometrical comparison between Northern Cameroon and Chad goat. Rev. Elev. Méd. Vét. Pays Trop, 46: 667-674.

Cam, M., M. Olfaz and E. Soydan, 2010. Possibilities of using morphometrics characteristics as a tool for body weight prediction in Turkish hair goats (Kilkeci). Asian J. Anim. Vet. Adv., 5: 52-59. DOI: 10.3923/ajava.2010.52.59

Campbell, Q.P., 2003. The origin and description of southern Africa's indigenous goats. South African J. Anim. Sci., 4: 18-22.

Delgado, J.V., C. Barba, M.E. Camacho, F.T.P.S. Sereno and A. Martinez et al., 2001. Livestock characterisation in Spain. AGRI, 29: 7-18. DOI: $10.1017 / \mathrm{S} 1014233900005162$

Dossa, L.H., C. Wollny and M. Gauly, 2007. Spatial variation in goat populations from Benin as revealed by multivariate analysis of morphological traits. Small Rum. Res., 73: 150-159.

DOI: $10.1016 /$ j.smallrumres.2007.01.003

Duguma, G., T. Mirkena, A. Haile, L. Iniguez and A.M. Okeyo et al., 2010. Participatory approaches to investigate breeding objectives of livestock keepers. Livest Res. Rural Dev.

FAO, 2012. Food and agriculture organization of the united nations phenotypic characterization of animal genetic resources. FAO Animal Production Health Guidelines.

Fontanesi, L., S. Dall'Olio, F. Beretti, B. Portolano and V. Russo, 2011. Coat colours in the massese sheep breed are associated with mutations in the Agouti Signalling Protein (ASIP) and Melanocortin 1 Receptor (MC1R) genes. Animal, 5: 8-17. DOI: $10.1017 / \mathrm{S} 1751731110001382$

González, A., M. Luque, E. Rodero, C. González and R. Aguilera et al., 2011. Use of morphometric variables for differentiating Spanish hound breeds. Int. J. Morphol., 29: 1248-1255. DOI: $10.4067 /$ S0717-95022011000400030

Gwaze, F.R., M. Chimonyo and K. Dzama, 2009. Communal goat production in Southern Africa: A review. Tropical Anim. Health Prod., 41: 1157-1168. DOI: $10.1007 / \mathrm{s} 11250-008-9296-1$

Hagan, J.K., S.O. Apori, M. Bosompem, G. Ankobea and A. Mawuli, 2012. Morphological characteristics of indigenous goats in the coastal savannah and forest eco-zones of Ghana. J. Anim. Sci. Adv., 2: 813-821.
Hassen, H., M. Baum, B. Rischkowsky and M. Tibbo, 2012. Phenotypic characterization of Ethiopian indigenous goat populations. African J. Biotechnol., 11: 13838-13846. DOI: $10.5897 / \mathrm{AJB} 12.2092$

Idowu, P.A. and O.A. Adelabu, 2018. An investigation of coat colour distribution of West African dwarf goats. J. Agric. Sci., 10: 228-236. DOI: $10.5539 /$ jas.v10n3p228

Jimcy, J., K.C. Raghavan and K.S. Sujatha, 2011. Diversity of local goats in Kerala, India, based on morpho-biometric traits. Livestock Res. Rural Dev.

Katongole, J.B.D., B. Sebolai and M.J. Madimabe, 1996. Morphological characterization of the Tswana goat. Proceeding of the 3rd Biennial Conference of the African Small Ruminant Research Network, Dec. 5-9, UICC, Kampala, Uganda, pp: 43-46.

Kotze, A., J.P. Grobler, E. van Marle-Koster, T. Jonker and D.L. Dalton, 2014. The Tankwa Karoo National Park feral goat population: A unique genetic resource. South African J. Anim. Sci., 44: 43-48. DOI: $10.4314 /$ sajas.v44i1.6

Kruger, A.C. and S.S. Sekele, 2013. Trends in extreme temperature indices in South Africa: 1962-2009. Int. J. Climatol., 33: 661-676. DOI: $10.1002 /$ joc. 3455

Kunene, N.W., S. Ceccobelli, P. Di Lorenzo, S.R. Hlophe and C.C. Bezuidenhout et al., 2014. Genetic diversity in four populations of Nguni (Zulu) sheep assessed by microsatellite analysis. Italian J. Anim. Sci., 13: 76-82.

Kunene, N. and A. Fossey, 2006. A survey on livestock production in some traditional areas of Northern Kwazulu Natal in South Africa. Livestock Res. Rural Dev., 18: 30-33.

Lanari, M.R., H. Taddeo, E. Domingo, M.P. Centeno an L. Gallo, 2003. Phenotypic differentiation of exterior traits in local Criollo goat population in Patagonia (Argentina). Arch Tierz Dummerstorf, 46: 347-356.

Mahanjana, A.M. and P.B. Cronjé, 2000. Factors affecting goat production in a communal farming system in the Eastern Cape region of South Africa. South African J. Anim. Sci., 30: 149-154.

Mashau, T.D., 2013. Occultism in an African context: A case for the Vhavenda-speaking people of the Limpopo Province. In die Skriflig, 41: 637-653.

Manzi, M., T. Rutagwenda, N. Kanuya and P. Chatikobo, 2011. Phenotypic characterization of goats raised under traditional husbandry systems in Bugesera and Nyagatare districts of Rwanda. J. Anim. Vet. Adv., 10: 3297-3302. 
Mavule, B.S., F.M. Sarti, E. Lasagna and N.W. Kunene, 2016. Morphological differentiation amongst Zulu sheep populations in KwaZulu-Natal, South Africa, as revealed by multivariate analysis. Small Ruminant Res.

Mdladla, K., 2016. Landscape genomic approach to investigate genetic adaptation in South African indigenous goat populations. MSc Thesis.

Mdladla, K., E.F. Dzomba and F.C. Muchadeyi, 2017.Characterization of the village goat production systems in the rural communities of the Eastern Cape, KwaZulu-Natal, Limpopo and North West Provinces of South Africa. Tropical Anim. Health Prod., 49: 515-527.

DOI: $10.1007 / \mathrm{s} 11250-017-1223-\mathrm{x}$.

Mohmmed, D. and J.D. Amin, 1997. Estimating body weight from morphometric measurements of Sahel (Borno White) goats. Small Ruminant Res., 24: 1-5.

Morrison, J.W., 2007. A guide to the identification of the natural indigenous goats of Southern Africa.

Okpeku, M., A. Yakubu, S. Olusolapeters, M.O. Ozoje and C.O. Ikeobi et al., 2011. Application of multivariate principal component analysis to morphological characterization of indigenous goats in southern Nigeria. Acta Agric. Slovenica, 98: 101-109.

Okourwa, M.I., 2015. Effect of coat characteristics on physiological traits and heat tolerance of West African Dwarf sheep in Southern Nigeria. Open J. Anim. Sci., 5: 351-357. DOI: 10.4236/ojas.2015.54039.

Osinowo, O.A., V. Buvanendram and N.L. Koning, 1988. A study of coat type, pigmentation and wattle incidence in Yankasa sheep and their effects on fertility and weaning weight. Proceedings of the 13th Annual Conference of the Nig-Soc, (CNS' 88).

Pieters, A., E. van Marle-Koster, C. Visser and A. Kotze, 2009. South African developed meat type goats: A forgotten animal genetic resource? Anim. Genetic Res. Inform., 44: 33-43. DOI: $10.1017 / \mathrm{S} 1014233900002844$.

Riva, J., R. Rizzi, S. Marelli and L.G. Cavalchini, 2004. Body measurements in Bergamasca sheep. Small Rum. Res., 55: 221-227.

DOI: $10.1016 /$ j.smallrumres.2003.12.010.

Roessler, R., A.G. Drucker, R. Scarpa, A. Markemann and U. Lemke et al., 2008. Using choice experiments to assess smallholder farmers' preferences for pig breeding traits in different production systems in North-West Vietnam. Ecol. Econo., 66: 184-192.

DOI: $10.1016 /$ j.ecolecon.2007.08.023

SAS Institute Inc., 2014. SAS/ETS user's guide, Version 13.1. Cary. NC: SAS Institute INC.
Schulze, R.E., B.C. Hewitson, K.R. Barichievy, MA. Tadross and R.P. Kunz et al., 2010. Methodological approaches to assessing eco-hydrological responses to climate change in South Africa. South Africa: Water Research Commission; Report No.: Rep. $1562 / 1 / 10$.

Semakula, J., D. Mutetikka, R.D. Kugonza and D. Mpairewe, 2010. Variability in body morphometric measurements and their application in predicting live body weight of mubende and Small East African goat breeds in Uganda. Middle-East J. Sci. Res., 5: 98-105. DOI: 10.3923/aj.2010.89.97

Sowande, O.S., B.F. Oyewale and O.S. Iyasere, 2009. Age and sex dependent regression models for predicting the live weight of West African dwarf goat from body measurements. Tropical Anim. Health Prod., 42: 969-975 DOI: $10.1007 / \mathrm{s} 11250-009-9515-4$

Traoré, A., H.H. Tamboura, A. Kabore, L.J. Royo and I. Fernandez et al., 2008. Multivariate analyses on morphological traits of goats in Burkina Faso. Archiv. Tierzucht, 51: 588-600.

DOI: $10.5194 / \mathrm{aab}-51-588-2008$

Tsegaye, D., B. Belay and A. Haile, 2013. Morphological characterization of indigenous Hararghe highland goat breeds in their native environment, West Haraghe, Ethiopia. Am. Eur. J. Sci. Res., 8: 72-79.

Yakubu, A., A. Salako and I. Imumorin, 2010a. Multivariate analysis of spatial patterns of morphological traits in West African Dwarf goats in three agro-ecological zones of Nigeria. J. Applied Anim. Res., 38: 257-260.

DOI: $10.1080 / 09712119.2010 .10539522$

Yakubu, A., A. Salako, I. Imumorin, A. Ige and M. Akinyemi, 2010b. Discriminant analysis of morphometric differentiation in the West African Dwarf and Red Sokoto goats. South African J. Anim. Sci., 40: 381-387. DOI: 10.4314 /sajas.v40i4.65261

Yakubu, A., A.E. Salako, I.G. Imumorin, A.O. Ige and M.O. Akinyemi, 2010c. Discriminant analysis of morphometric differentiation in the West African Dwarf and Red Sokoto goats. South African J. Anim. Sci., 40: 381-387. DOI: $10.4314 /$ sajas.v40i4.65261 